Vol. 2, No. 4, pp. 153-161, 2021

\title{
Typological Analysis and Development of District Area Based on Potential Sectors in Pasaman Regency, West Sumatera Province, Indonesia
}

\author{
Deop Darius*, Abd Jamal, Putri Bintusy Syathi \\ Department of Economics, Faculty of Economics and Business, Syiah Kuala University, Darussalam, Banda Aceh, Indonesia \\ *Corresponding author email: deopdarius@gmail.com
}

\begin{abstract}
The decentralization of Indonesia allowed the development in the regency level to improve to the highest level. However, the impact can only be maximized by utilizing the potential economy embodied in the regent. This study investigates the development of the Pasaman Regency by analyzing the potential sector and the stage development of the sector. Therefore, this study uses mixed research methods with explorative approaches and uses Contribution Sectors Analysis, Location Quotient Analysis model, Shift Share Analysis model, and Klassen typological analysis model, The data used is the Gross Regional Domestic Product (GRDP) of Pasaman Regency and West Sumatra Province in the period 2010 until 2019 and data on the production of the Pasaman Regency base sector in each district in 2015-2019. The result showed that the agricultural, fisheries, and forestry sectors have the largest contribution to the GRDP of Pasaman Regency which is 55.51\%, then the sector that belongs to the base sector with the value of LQ>1, namely the agricultural, fisheries, and forestry sectors. The sectors that experienced a net change or shift and had a positive value and the highest level of excellence were the agricultural, fisheries, and forestry sectors of 10,718,410,000. Klassen Typology Analysis is based on the base sector, namely the agricultural, fisheries, and forestry sectors with the largest contribution to the fisheries sector so that the grouping of regions using fisheries data with the results of Panti and South Rao Districts is classified as advanced areas and Lubuk Sikaping and Mapat Tunggul Selatan districts are classified as lagging areas. There is a shift in territory caused by land transfer, changes in the profession, and accessibility. The development of district areas in Pasaman Regency through the fishery sector in the form of fish cultivation, fish feed factories, and fish processing industries is expected to improve the welfare of the community, especially sub-districts that are not classified as developed areas so that the trickle-down effect and the realization of equitable distribution
\end{abstract} Keywords: Regional Development, Regional typology, Potential Sectors

\section{Introduction}

The purpose of development is essential to equalize welfare and justice indicated by the ability of the community in the fulfillment of basic needs, improvement of quality of life, and the smaller inequality between residents, regions, and sectors. Regional differences indicate that there are differences in natural resources, human resources that have limitations and obstacles from the government due to access to environmental differences, so it greatly affects the success of the government to develop and advance the economy of a region in addition to the government trying to find the potential of an area that stimulates economic growth (Kurniawan and Managi, 2018; Wintara et al., 2021; Pusra et al., 2021). The potential of a region is greater than other regions will cause stimuli in other regions so that economic growth through the economic sector will increase and help other sectors that still do not appear to be growing and economic development is expected to occur equalization of developments in all sectors of the economy in a region (Suryahadi et al. 2012; Khaliq and Noy, 2007; Sendouw, 2014).

Pasaman regency is one of the areas in West Sumatra Province that is traversed by cross-Sumatra roads that directly border the Province of North Sumatra and is one of the areas crossed by the equator and continue to make various developments in the region to increase Gross Regional Domestic Product (GRDP) (Sukono et al., 2019; Feriyanto et al., 2020; Darma, 2020). The comparison of GRDP at current market prices and GRDP Per Capita can be seen in Table 1 . 
Table 1 Comparison of GRDP at Current Market Prices and Per Capita (In billions of Rupiah), 2014-2019

\begin{tabular}{ccccccc}
\hline \multirow{2}{*}{ Year } & \multicolumn{2}{c}{ Sumatera } & \multicolumn{2}{c}{ West Sumatera Province } & \multicolumn{2}{c}{ Pasaman Regency } \\
\cline { 2 - 6 } & $\begin{array}{c}\text { GRDP at } \\
\text { Current } \\
\text { Market Prices }\end{array}$ & $\begin{array}{c}\text { GRDP } \\
\text { perCapita }\end{array}$ & $\begin{array}{c}\text { GRDP at } \\
\text { current } \\
\text { market prices }\end{array}$ & $\begin{array}{c}\text { GRDP } \\
\text { perCapita }\end{array}$ & $\begin{array}{c}\text { GRDP at } \\
\text { current } \\
\text { market prices }\end{array}$ & $\begin{array}{c}\text { GRDP } \\
\text { perCapita }\end{array}$ \\
\hline$(1)$ & $(2)$ & $(3)$ & $(4)$ & $(5)$ & $(6)$ & $(7)$ \\
\hline 2014 & $2,458,866$ & 45,190 & 164,944 & 32,141 & 5,951 & 22,299 \\
2015 & $2,584,134$ & 46,752 & 179,952 & 34,631 & 6,505 & 24,104 \\
2016 & $2,781,629$ & 49,566 & 196,099 & 37,285 & 7,336 & 26,890 \\
2017 & $2,986,505$ & 52,440 & 213,893 & 40,194 & 7,802 & 28,296 \\
2018 & $3,233,250$ & 55,973 & 230,572 & 42,841 & 8,321 & 29,879 \\
2019 & $3,583,729$ & 59,264 & 246,423 & 45,288 & 8,909 & 31,679 \\
\hline
\end{tabular}

Source: Agency Statistic of Indonesia

The economy of Pasaman Regency in the period 2014 - 2018 grew above $5 \%$, namely $5.87 \%$ (2014), $5.34 \%$ (2015), $5.07 \%$ (2016), $5.09 \%$ (2017), and $5.01 \%$ (2018). Although there was an increase in economic growth not comparable to the growth rate of GRDP Pasaman Regency in 2018 only reached $5.01 \%$ with the lowest predicate in West Sumatra. This resulted in Pasaman Regency occupying the fifth highest position of poor people in the province of West Sumatra and the Human Development Index ranked $18^{\text {th }}$ out of 19 regencies/cities in West Sumatra at 66.46 $\%$ in 2019.

Table 2. The Number of Human Development Index and Growth by Regency/ City for 2015 to 2019

\begin{tabular}{|c|c|c|c|c|c|c|c|c|c|}
\hline \multirow{3}{*}{$\begin{array}{c}\text { Regencies/cities } \\
\text { (1) }\end{array}$} & \multicolumn{5}{|c|}{ HDI } & \multicolumn{4}{|c|}{ HDI Growth (\%) } \\
\hline & 2015 & 2016 & 2017 & 2018 & 2019 & 2016 & 2017 & 2018 & 2019 \\
\hline & (2) & (3) & (4) & $(5)$ & (6) & (7) & (8) & (9) & $(10)$ \\
\hline Kep. Mentawai & 57.41 & 58.27 & 59.25 & 60.28 & 61.26 & 1.48 & 1.65 & 1.71 & 1.60 \\
\hline Pesisir Selatan & 68.07 & 68.39 & 68.74 & 69.40 & 70.08 & 0.47 & 0.51 & 0.95 & 0.97 \\
\hline Kab. Solok & 67.12 & 67.67 & 67.86 & 68.60 & 69.08 & 0.81 & 0.28 & 1.08 & 0.69 \\
\hline Sijunjung & 65.30 & 66.01 & 66.60 & 66.97 & 67.66 & 1.08 & 0.89 & 0.55 & 1.02 \\
\hline Tanah Datar & 69.49 & 70.11 & 70.37 & 71.25 & 72.14 & 0.88 & 0.37 & 1.24 & 1.23 \\
\hline Padang Pariaman & 68.04 & 68.44 & 68.90 & 69.71 & 70.59 & 0.58 & 0.67 & 1.16 & 1.25 \\
\hline Agam & 69.84 & 70.36 & 71.10 & 71.70 & 72.37 & 0.74 & 1.04 & 0.84 & 0.93 \\
\hline Lima Puluh Kota & 67.65 & 68.37 & 68.69 & 69.17 & 69.67 & 1.05 & 0.47 & 0.69 & 0.72 \\
\hline Pasaman & 64.01 & 64.57 & 64.94 & 65.60 & 66.46 & 0.87 & 0.57 & 1.01 & 1.29 \\
\hline Solok Selatan & 67.09 & 67.47 & 67.81 & 68.45 & 68.94 & 0.56 & 0.50 & 0.93 & 0.71 \\
\hline Dharmasraya & 69.84 & 70.25 & 70.40 & 70.86 & 71.52 & 0.58 & 0.21 & 0.65 & 0.92 \\
\hline Pasaman Barat & 65.26 & 66.03 & 66.83 & 67.43 & 68.21 & 1.17 & 1.20 & 0.89 & 1.14 \\
\hline Padang & 80.36 & 81.06 & 81.58 & 82.25 & 82.68 & 0.86 & 0.64 & 0.81 & 0.52 \\
\hline Kota Solok & 76.83 & 77.07 & 77.44 & 77.89 & 78.38 & 0.31 & 0.48 & 0.58 & 0.63 \\
\hline Sawahlunto & 69.87 & 70.67 & 71.13 & 71.72 & 72.39 & 1.13 & 0.65 & 0.82 & 0.93 \\
\hline Padang Panjang & 75.98 & 76.50 & 77.01 & 77.30 & 78.00 & 0.68 & 0.66 & 0.38 & 0.90 \\
\hline Bukittinggi & 78.72 & 79.11 & 79.80 & 80.11 & 80.71 & 0.49 & 0.86 & 0.39 & 0.74 \\
\hline Payakumbuh & 77.42 & 77.56 & 77.91 & 78.23 & 78.95 & 0.18 & 0.45 & 0.41 & 0.91 \\
\hline Pariaman & 74.98 & 75.44 & 75.71 & 76.26 & 76.70 & 0.61 & 0.36 & 0.72 & 0.57 \\
\hline $\begin{array}{c}\text { West Sumatera } \\
\text { Province }\end{array}$ & 69.98 & $\mathbf{7 0 . 7 3}$ & 71.24 & 71.73 & 72.39 & 1.06 & 0.72 & 0.68 & 0.91 \\
\hline
\end{tabular}

Source: Agency Statistic of West Sumatera Province

The low HDI rate and the high percentage of poverty caused by the economy of Pasaman Regency have not been passionate because the existing economic sectors have not been optimized for development and the government seems to have no innovation in how the economic prospects of Pasaman Regency and how the standard of living or quality of life of the people can be improved. Residents of Pasaman Regency mostly have a livelihood in agriculture of $56 \%$, industry of $15 \%$, trade of $16 \%$, construction of $3 \%$, and transportation of $1 \%$. Therefore, innovation and assessment 
of the potential of renewable areas are needed in the framework of the development to improve the regional economy and society as well as improve the quality of life of the people of Pasaman Regency.

The condition of the district in Pasaman Regency is very diverse, so to develop the area must know the typology of each district. Areas such as Bonjol, Panti, and Lubuk Sikaping subdistricts have hill areas, extensive forests and long streams, Padang Gelugur, Duo Koto, and Rao districts tend to be flat areas and many small and medium-sized industries as well as many sugar cane plantations and fish cultivation. and in Pasaman Regency there are superior tourism objects, namely the Rimbo Panti area and Bonjol area, but not included in the list of tourist destinations in West Sumatra because of the alarming and unkempt conditions. it shows that there is no attraction and impact to improve the economy so it becomes one of the causes of the economy of Pasaman Regency is far behind compared to other regions in West Sumatra. The main objective of this study is to investigate the development of the Pasaman Regency by analyzing the potential sector and the development stage of the sector.

\section{Literature Review}

Economic growth is basically to achieve prosperity in a region or region determined by the added value of a region and its influence on the transfer of payments or the flow of income within the region or out of the region (Acemoglu, 2012). Development planning in an area should pay attention to the conditions of the region to make it easier to take regional development policies by determining or classifying development priority areas to achieve the goals and targets of welfare equality, in addition to being a material evaluation of policymakers to accelerate the development of disadvantaged areas and regions (Beard, 2005) .

location selection is determined based on accessibility principles that prioritize ease of reach so that economic activity can reduce economic risks (Capello, 2021) and development in the development of the region needs to be considered accessibility because it greatly affects the development and economic growth of the region or a location (Barbero and Zofío, 2016). But a region that has a low level of spatial interrelationship will give rise to the potential for random spatial patterns/ locations, meaning that adjacent locations in a region lack influence or attraction to others. The government in this case is required to find, process, and develop potential sectors in the region with the aim of economic development and attract investors as a trigger for economic growth and create a multiplier effect on other sectors (Marhamah and Jamal, 2016).

Implementation of development in an area is carried out through regional development by prioritizing the superior and potential sectors for increased income and regional independence (Yang et al., 2018). Regional development in regencies/cities in each district has a classification of areas and potential sectors so it is necessary to group the areas. Regional development policies that do not pay attention to the potential of the region do not have a positive influence on the improvement of the economy of a region (Ramadhan et al., 2020). Regional development can be done by developing the potential or economic sector that is the leading commodity in the region into a new economic sector (Kairupan \& Manoppo, 2021).

The regional typology provides the basis for determining the priority area of development in the framework of the development of the right area and has a positive impact on the region and its surroundings and realizes equality. Based on the results of research that states that the direction of regional development, especially the economic improvement of West Sumatra Province is directed at areas classified as disadvantaged areas and Pasaman Regency belongs to the category of disadvantaged areas in the study, so that is the basis of the author to research typology and potential sectors in Pasaman Regency so that the potential sectors in each district can be raised to be developed to be the drivers of the community economy for the better.

\section{Materials and Methods}

\subsection{Materials}

This research was conducted in Pasaman Regency using a mixed research method, namely qualitative and quantitative research through an explorative approach. The data used is primary data in the form of interviews and observations, then secondary data in the form of data on Gross Domestic Regional Products (GDRP) Pasaman regency and West Sumatra province data period from 2010-2019 and data on the production of the economic base sector of Pasaman Regency in each district from 2015-2019.

\subsection{Methods}

\subsubsection{Sectoral Contribution Analysis}

Sectoral Contribution Analysis is used to see the distribution of sectoral percentages that make up Pasaman Regency's GDP so that it is known the economic sector to be developed with the following equation (Yudhistira and Sofiyandi, 2018): 


$$
S t=\left(\frac{V i}{V}\right) \times 100
$$

Where:

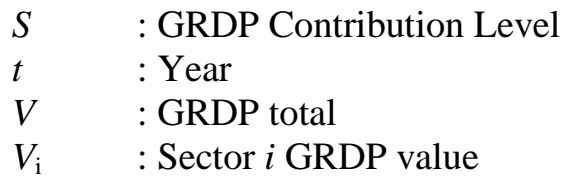

\subsubsection{Location Quotient Analysis}

Location Quotient (LQ) analysis is used to compare the magnitude of the role of the sector of an area (sub-district in Pasaman Regency) which serves to identify internal potentials in each sub-district, namely the basic and non-base sectors (Yusri et al., 2018).

$$
\mathrm{LQ}=\frac{S i / s}{P i / p}
$$

Where :

Si : : GRDP sector i of Pasaman Regency year-n

S : : GRDP total of Pasaman Regency year-n

$\mathrm{Pi} \quad$ : GRDP sector i of West Sumatera Province year-n

P : : GRDP total of West Sumatera Province year-n

The results of the LQ analysis can be interpreted as follows:

1. If the value of $L Q>1$, indicates a concentration of the economic sector at the Regency level relatively compared to the total Province or there is a surplus and the sector is the base sector in the Regency.

2. If the value of $\mathrm{LQ}=1$, the district's economic sector has activities equivalent to that of the province.

3 . If the value of $L Q<1$, then the district level has a smaller concentration of the economic sector than the province.

\subsubsection{Shift Share Analysis}

Shift Share analysis in this study is used as an analytical tool to provide information about the performance of the economic sector and determine changes or shifts in the economic sector in Pasaman Regency compared to West Sumatra Province with the following equation:

$$
\begin{aligned}
& D_{\mathrm{ij}}=N_{\mathrm{ij}}\left(R_{\mathrm{n}} \times R_{\mathrm{ij}}\right)+M_{\mathrm{ij}}\left(R_{\mathrm{n}} \times R_{\mathrm{in}} \times i j\right)+\mathrm{C}_{\mathrm{ij}}\left(R_{\mathrm{ij}}-R_{\mathrm{in}} \times i t\right) \\
& D_{\mathrm{ij}}=N_{\mathrm{ij}}+M_{\mathrm{ij}}+C_{\mathrm{ij}}
\end{aligned}
$$

Where :

$D_{\mathrm{ij}} \quad$ : Shift GRDP in Sector $i$ of Pasaman Regency

$N_{\mathrm{ij}} \quad$ : National Economic Growth or Reference Rate

$M_{\mathrm{ij}} \quad$ : Proportional Shift

$C_{\mathrm{ij}} \quad$ : Level of Competitive advantage

\subsubsection{Klassen Typology Analysis}

Klassen typology analysis is an analytical tool that serves to see an overview of the patterns and structure of regional economic growth. The areas that are observed in the group into four classifications are: fast-forward and growing regions (prime sector), developed but depressed areas (developing sectors), fast-growing areas (potential sectors), and relatively lagging areas (underdeveloped sectors) (Fattah and Rahman, 2013). The Klassen typology analysis can be seen in Table 3 . 
Table 3. Klassen Typology Analysis

\begin{tabular}{ccc}
\hline Rate of Production $(r)$ & $r \mathrm{i}<R$ & $R \mathrm{i}>R$ \\
Production $(y)$ & $\begin{array}{c}\text { Quadrant II ( Developed } \\
\text { but Depressed Areas ) }\end{array}$ & Quadrant I (Developed Regions) \\
\hline$y \mathrm{i}>Y$ & $\begin{array}{c}\text { Quadrant IV (Relatively } \\
\text { Disadvantaged Areas) }\end{array}$ & Quadrant III (Developing Regions) \\
\hline
\end{tabular}

Information :

$y_{\mathrm{i}}$ : Production of the economic base sector at the district of Pasaman Regency

$y$ : Total production of the economic base sector of Pasaman Regency

$r_{\mathrm{i}}$ : Business actors of the economic base sector at the district of Pasaman Regency

$R$ : Total business actors' sector economic base of Pasaman Regency

\section{Results and Discussion}

\subsection{Sectoral Contribution Analysis}

The sectoral contribution analysis is useful for knowing the magnitude of the distribution of each economic sector on the formation of the Pasaman Regency GRDP as a basis for developing potential sectors. The GRDP Contribution per Economic Sector of Pasaman Regency 2010-2019 can be seen in Table 4.

Table 4. GRDP Contribution per Economic Sector of Pasaman Regency 2010-2019 (Percent)

\begin{tabular}{|c|c|c|c|c|c|c|c|c|c|c|}
\hline Year & $\begin{array}{l}\text { Agriculture, } \\
\text { forestry, and } \\
\text { fishery }\end{array}$ & $\begin{array}{l}\text { Mining } \\
\text { and } \\
\text { quarryin } \\
\mathrm{g}\end{array}$ & $\begin{array}{l}\text { Manufa } \\
\text { cturing }\end{array}$ & $\begin{array}{l}\text { construc } \\
\text { tion }\end{array}$ & $\begin{array}{l}\text { Large } \\
\text { trade, } \\
\text { retail, and } \\
\text { reparation }\end{array}$ & $\begin{array}{c}\text { Transport } \\
\text { ation and } \\
\text { warehous } \\
\text { ing }\end{array}$ & $\begin{array}{l}\text { Providing } \\
\text { accommod } \\
\text { ation, } \\
\text { eating, and } \\
\text { drinking }\end{array}$ & $\begin{array}{l}\text { Informa } \\
\text { tion and } \\
\text { comuni } \\
\text { cation }\end{array}$ & $\begin{array}{l}\text { Governm } \\
\text { ent } \\
\text { administr } \\
\text { ation and } \\
\text { social } \\
\text { security }\end{array}$ & $\begin{array}{l}\text { Comp } \\
\text { any } \\
\text { servic } \\
\text { es }\end{array}$ \\
\hline (1) & (2) & (3) & (4) & (5) & (6) & (7) & (8) & (9) & (10) & (11) \\
\hline 2010 & 56.14 & 2.14 & 4.40 & 3.88 & 11.45 & 3.21 & 0.76 & 0.93 & 17.05 & 0.04 \\
\hline 2011 & 56.18 & 1.98 & 4.19 & 3.92 & 11.46 & 3.10 & 0.80 & 1.13 & 17.20 & 0.04 \\
\hline 2012 & 55.36 & 1.83 & 3.98 & 3.91 & 13.03 & 3.00 & 0.75 & 1.17 & 16.93 & 0.04 \\
\hline 2013 & 56.06 & 2.19 & 5.43 & 5.01 & 13.55 & 4.59 & 0.83 & 4.37 & 7.91 & 0.06 \\
\hline 2014 & 56.68 & 2.39 & 5.09 & 4.82 & 13.50 & 4.70 & 0.85 & 4.37 & 7.54 & 0.06 \\
\hline 2015 & 56.39 & 2.40 & 4.83 & 5.05 & 14.26 & 4.68 & 0.90 & 4.15 & 7.29 & 0.06 \\
\hline 2016 & 55.76 & 2.22 & 4.96 & 5.21 & 14.38 & 4.87 & 0.96 & 4.34 & 7.26 & 0.06 \\
\hline 2017 & 55.58 & 2.26 & 4.75 & 5.32 & 14.28 & 4.92 & 0.97 & 4.47 & 7.39 & 0.06 \\
\hline 2018 & 54.54 & 2.26 & 4.56 & 5.64 & 14.67 & 5.07 & 1.01 & 4.77 & 7.43 & 0.06 \\
\hline 2019 & 52.38 & 2.22 & 4.29 & 5.99 & 15.47 & 5.37 & 1.10 & 5.23 & 7.88 & 0.06 \\
\hline $\begin{array}{l}\text { aver } \\
\text { age }\end{array}$ & 55.51 & 2.19 & 4.65 & 4.88 & 13.60 & 4.35 & 0.89 & 3.49 & 10.39 & 0.05 \\
\hline
\end{tabular}

Source: Agency Statistic of Pasaman Regency, processed data

The agricultural, forestry, and fishery sectors have a very large contribution to the formation of the GRDP of Pasaman Regency, namely $55.51 \%$, which means that the sector is the leading sector. Followed by the wholesale and retail sector, which shows a fairly large contribution to the GRDP of Pasaman Regency, namely $13.60 \%$. The results of the analysis show that the development of potential sectors comes from the agricultural and trade sectors by carrying out creative economic innovations from these sectors to produce a renewable economic sector.

\subsection{Location Quotient Analysis}

Location Quotient analysis is useful for determining the sector that is the economic base of Pasaman Regency as the basis for developing potential sectors 
Table 5 Location Quotient Analysis of Pasaman Regency 2010-2019

\begin{tabular}{|c|c|c|c|c|c|c|c|c|c|c|c|c|}
\hline \multirow{2}{*}{ Sector } & \multicolumn{10}{|c|}{ Location Quotient Analysis of Pasaman Regency in 2010-2019 } & \multirow[t]{2}{*}{ average } & \multirow[t]{2}{*}{ description } \\
\hline & 2010 & 2011 & 2012 & 2013 & 2014 & 2015 & 2016 & 2017 & 2018 & 2019 & & \\
\hline (1) & (2) & (3) & (4) & (5) & (6) & (7) & (8) & (9) & (10) & (11) & (12) & (13) \\
\hline $\begin{array}{l}\text { Agriculture, forestry, and } \\
\text { fishery }\end{array}$ & 1.82 & 1.84 & 1.84 & 1.89 & 1.89 & 1.95 & 1.95 & 1.98 & 1.88 & 1.96 & 1.90 & base \\
\hline Mining and quarrying & 0.40 & 0.37 & 0.34 & 0.40 & 0.41 & 0.42 & 0.41 & 0.44 & 0.42 & 0.43 & 0.41 & non base \\
\hline Manufacturing & 0.32 & 0.30 & 0.29 & 0.41 & 0.40 & 0.41 & 0.41 & 0.41 & 0.40 & 0.43 & 0.38 & non base \\
\hline contru & 0.41 & 0.41 & 0.39 & 0.48 & 0.44 & 0.46 & 0.47 & 0.48 & 0.47 & 0.49 & 0.45 & non base \\
\hline $\begin{array}{l}\text { Large trade, retail, and } \\
\text { reparation }\end{array}$ & 0.94 & 0.95 & 1.05 & 1.04 & 1.03 & 1.11 & 1.14 & 1.10 & 1.02 & 1.07 & 1.05 & base \\
\hline $\begin{array}{l}\text { Transportation and } \\
\text { warehousing }\end{array}$ & 0.26 & 0.25 & 0.24 & 0.34 & 0.33 & 0.33 & 0.33 & 0.33 & 0.49 & 0.35 & 0.32 & non base \\
\hline $\begin{array}{l}\text { Providing } \\
\text { accommodation, eating } \\
\text { and drinking }\end{array}$ & 0.74 & 0.66 & 0.69 & 0.65 & 0.63 & 0.63 & 0.63 & 0.64 & 0.62 & 0.64 & 0.65 & non base \\
\hline $\begin{array}{l}\text { Information and } \\
\text { comunication }\end{array}$ & 0.14 & 0.18 & 0.18 & 0.70 & 0.72 & 0.70 & 0.73 & 0.71 & 0.70 & 0.75 & 0.55 & non base \\
\hline $\begin{array}{l}\text { Government } \\
\text { administration and social } \\
\text { security }\end{array}$ & 2.27 & 2.27 & 2.21 & 1.32 & 1.32 & 1.09 & 1.05 & 1.06 & 1.00 & 1.07 & 1.47 & base \\
\hline Company services & 0.08 & 0.08 & 0.08 & 0.11 & 0.11 & 0.12 & 0.11 & 0.11 & 0.11 & 0.11 & 0.10 & non base \\
\hline
\end{tabular}

Source: Agency Statistic of Pasaman Regency, processed data

The result of LQ analysis in Table 5 indicates that the Agriculture, Forestry and Fisheries Sector, Wholesale and Retail Trade Sector and the Government Administration and Social Security sectors show a value of LQ>1, then the economic sector has a surplus compared to the total province and becomes the base sector. Other sectors show an LQ value $<1$, then these sectors have a smaller concentration compared to the total province and become a non-basic sector.

\subsection{Shift Share Analysis}

Shift Share analysis is used to provide information on the performance of the economic sector and determine changes or shifts in the economic sector in Pasaman Regency (See Table 6).

Table 6 Shift Share Analysis of Pasaman Regency (billion rupiah), 2010-2019

\begin{tabular}{lrrrr}
\hline \multicolumn{1}{c}{ GRDP } & \multicolumn{1}{c}{$\mathrm{Nij}$} & \multicolumn{1}{c}{$\mathrm{Mij}$} & \multicolumn{1}{c}{$\mathrm{Cij}$} & \multicolumn{1}{c}{ Dij } \\
\hline Agriculture, forestry, and fishery & $2,294,876$ & $2,301,981$ & 729,181 & $5,326,038$ \\
Mining and quarrying & 87,289 & 105,771 & 32,519 & 225,579 \\
Manufacturing & 179,743 & 122,303 & 117,086 & 419,132 \\
construction & 158,647 & 317,793 & 121,489 & 597,929 \\
Large trade, retail, and reparation & 689,111 & 998,578 & 361,249 & $2,048,938$ \\
Transportation and warehousing & 131,393 & 241,475 & 150,491 & 523,359 \\
Providing accommodation, eating, and & & & & \\
drinking & 36,350 & 82,970 & $-2,529$ & 116,791 \\
Information and comunication & 37,853 & 56,281 & 353,928 & 448,062 \\
Government administration and social & & & & \\
security & 696,925 & 888,090 & $-578,160$ & $1,006,854$ \\
Other services & 1,596 & 2,205 & 1,926 & 5,727 \\
\hline Total & $4,313,783$ & $5,117,448$ & $1,287,179$ & $10,718,410$ \\
\hline Source: Agency Statistic of Pasaman Regency, processed data & &
\end{tabular}

Table 6 shows the value of national growth or Regional Share (Nij) has a positive effect on every economic sector, this means that there is an increase in the GDRP of Pasaman Regency. The Proportional Shift (Mij) value for each sector shows a positive value that describes the relatively fast growth of each economic sector with the highest values being the agriculture, forestry, and fishery sectors $(2,301,981)$ followed by the large, small and retail trade sectors 
$(998,578)$ and the government administration and social security sectors. $(888,90)$. Competitive Shift (Cij) value shows that the agricultural, fishery, trade, information, transportation, and warehousing sectors have competitive advantages and have a significant influence on economic growth in Pasaman Regency.

Overall, the total increase in GRDP (Dij) in 2020-2019 Pasaman Regency is 10,718,410,000 rupiah and each sector has a positive value which illustrates that the net shift has a positive value. Of the ten economic sectors, only two economic sectors in Pasaman Regency have a level of competitive advantage and can be developed into a leading renewable sector, namely the agriculture, forestry, and fishery sectors and the trade sector.

Based on the results of a sectoral contribution analysis, LQ analysis, shift-share analysis, the basis for developing the Pasaman Regency area is from the agricultural, fishery, and trade sectors.

\subsection{Klassen Typology Analysis}

In 2019, there was a significant change where the subdistrict that was originally in quadrant I (developed area) shifted to quadrant III (developing area) namely Tigo Nagari District, Rao District, and North Rao district. Quadrant I district (advanced area) which shifts to quadrant IV (lagging area) is Lubuk Sikaping district. Quadrant II district (developed but depressed area) shifted to quadrant I (developed area) namely Panti district and South Rao district.

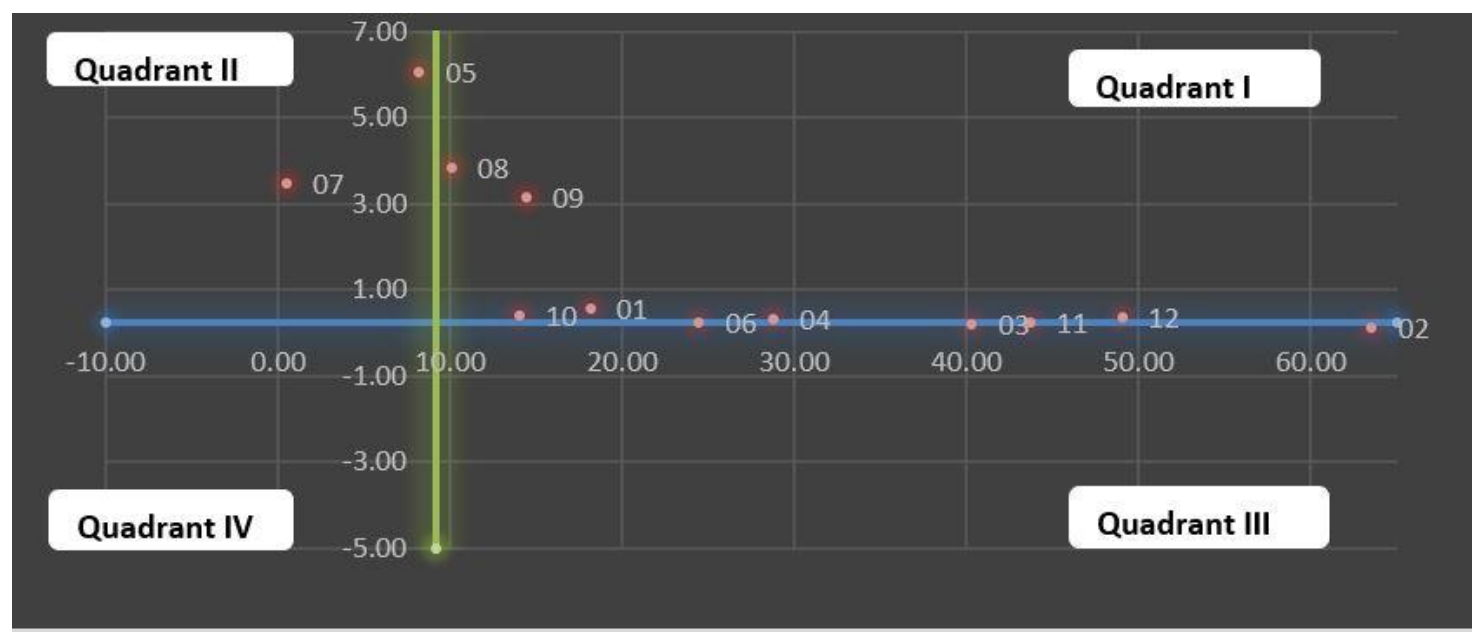

Figure 1. Typology of District Region Based on Fisheries Sector in 2015

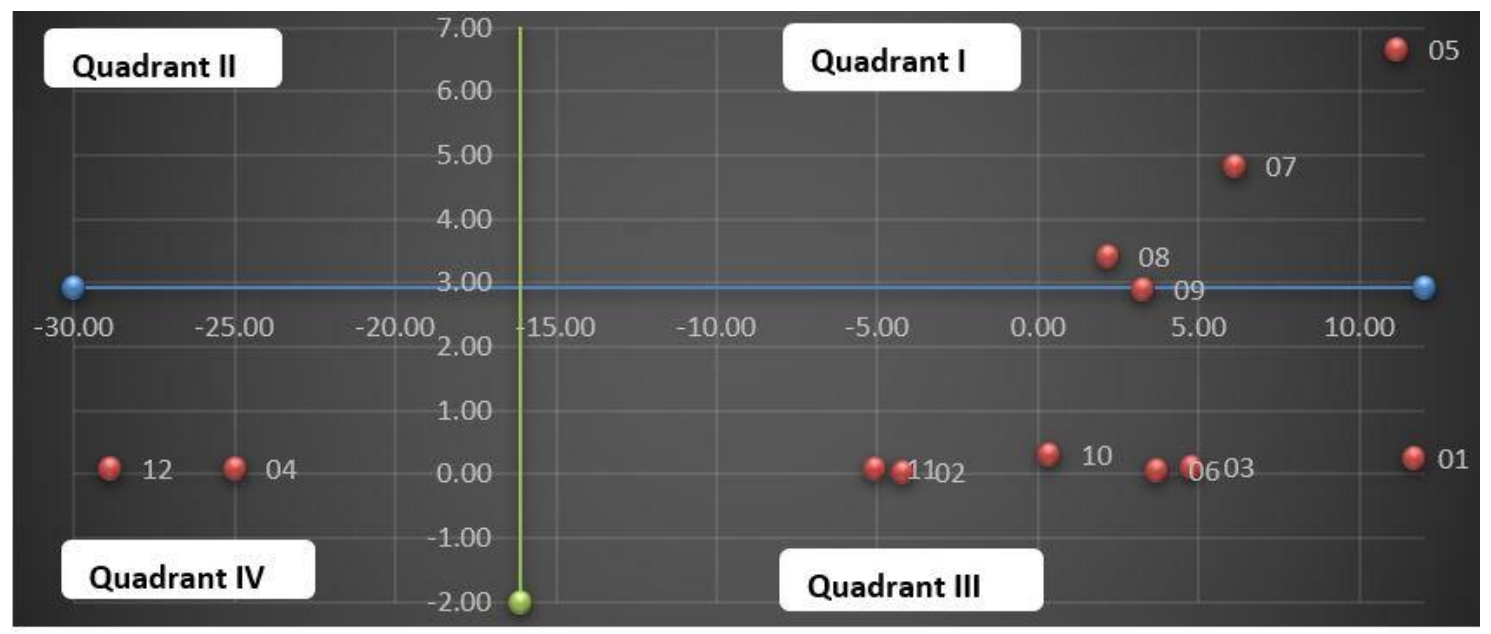

Figure 2. Typology of District Region Based on Fisheries Sector in 2019

Where :

01= Tigo Nagari District

02 $=$ Simpang Alahan Mati District

03= Bonjol District

04= Lubuk Sikaping District
05= Panti District

06 $=$ Duo Koto District

07 $=$ Rao Selatan District

08 $=$ Padang Gelugur District
$09=$ Rao District

$10=$ Rao Utara District

11= Mapat Tunggul District

$12=$ Mapat Tunggul Selatan District 
Regional shifts that occur based on the fisheries sector districts in Pasaman Regency are influenced by changes in land function, a transition of community professions, accessibility, and market conditions. Mapat Tunggul Selatan District in 2015 was classified as a developed area, it shifted to underdeveloped areas in 2019 due to accessibility to cultivation sites and markets, then the land conversion began to become rubber and oil palm plantations. Panti and South Rao Districts, which were originally located in depressed areas, shifted to developed areas because the Panti community began to take the fishery sector seriously by opening up a lot of fishery land and the strategic position of the area at the intersection of neighboring districts and South Rao will be used as a center for breeding and cultivation as well as factories. fish feed that creates new fish cultivators and new lands

\section{Conclusion}

This research was conducted in the context of developing districts in Pasaman Regency based on potential sectors by using several analytical models, namely sectoral contribution analysis, location quotient analysis, and shift-share analysis. Based on the results of research on the Pasaman Regency area coverage in 2010-2019, where the results of the analysis of sectoral contributions to Pasaman Regency's GRDP show that the agriculture, forestry, and fisheries sectors make a large contribution to the formation of Pasaman Regency's GRDP with an average of 55.51 percent and the sector trade by 13.60 percent.

The results of the location quotient analysis show that the agricultural, forestry, and fisheries sectors consistently obtain an LQ> 1 value every year, so they are still classified as basic sectors and can be seeded. The trade sector and the administrative services sector experienced fluctuations but were still classified as the base sector, where the trade sector experienced an increase in value which was originally classified as non-basic in 2010 and 2011 but from 2012 to 2019 became the base sector. While the administrative services sector has decreased with the lowest value in 2017 of 2.27 percent, in this case, the share given by the sector is decreasing.

Shift share analysis shows that the effect of national growth has a positive effect on each economic sector. Based on the proportional value, the growth of each economic sector is relatively fast, while the sectors that have a competitive advantage and a significant influence on economic growth in Pasaman Regency are the agriculture, forestry, and fishery sectors, the trade sector, and the information and communication sector.

This grouping of regions can be used to develop areas that are left behind and develop by utilizing the potential of fisheries in their territory and in areas that are classified as advanced so that the lagging and developing areas can also move and grow to the developed region from the fisheries side as in South Rao District has opened fishery land into the South Mapat Tunggul district which indicates the trickle-down effect has touched districts that are classified as lagging. This indicates that the attractiveness of advanced regions to disadvantaged regions is beginning to appear and this supports the central theory of growth As also researched by (Septian, 2019)

The development of district areas in Pasaman Regency will be more targeted by conducting economic development in developed areas based on the fisheries sector which is superior and potential to produce other economic sectors in the form of fish processing industry to produce new products such as souvenirs, then the opening of fish feed factories will make many new lands opened for fisheries, marketing of factory products and labor will be absorbed and the occurrence of equalization will be realized.

\section{References}

Acemoglu, D. (2012). Introduction to economic growth. Journal of economic theory, 147(2), 545-550.

Barbero, J., \& Zofío, J. L. (2016). The multiregional core-periphery model: The role of the spatial topology. Networks and Spatial Economics, 16(2), 469-496.

Beard, V. A. (2005). Individual determinants of participation in community development in Indonesia. Environment and Planning C: Government and Policy, 23(1), 21-39.

Capello, R. (2021). Classical Contributions: Von Thünen and Weber. Handbook of Regional Science, 61-80.

Darma, D. C. (2020). Determinants of the gross regional domestic product of east kalimantan province: Macroeconomic variable review. Review of Integrative Business and Economics Research, 9, 232-241.

Fattah, S., \& Rahman, A. (2013). Analysis of regional economic development in the regency/municipality at South Sulawesi province in Indonesia. Journal of Economics and Sustainable Development, 4(1), 1-9.

Feriyanto, N., El Aiyubbi, D., \& Nurdany, A. (2020). The Impact of Unemployment, Minimum Wage, and Real Gross Regional Domestic Product on Poverty Reduction in Provinces of Indonesia. Asian Economic and Financial Review, 10(10), 10881099. 
Kairupan, A. N., \& Manoppo, C. (2021). Analysis of economic potential areas based on farming agricultural sector in the border area of Sangihe Island Regency. In E3S Web of Conferences (Vol. 232, p. 01022). EDP Sciences.

Khaliq, A., \& Noy, I. (2007). Foreign direct investment and economic growth: Empirical evidence from sectoral data in Indonesia. Journal of Economic Literature, 45(1), 313-325.

Kurniawan, R., \& Managi, S. (2018). Economic growth and sustainable development in Indonesia: an assessment. Bulletin of Indonesian Economic Studies, 54(3), 339-361.

Marhamah, S., \& Jamal, A. (2016). Analisis Ketimpangan dan Perubahan Struktur Ekonomi Kawasan Basajan. Jurnal Ilmiah Mahasiswa Ekonomi Pembangunan, 1(1), 246-253.

Pusra, C. M., Srinita, S., \& Seftarita, C. (2021). Effect of Selected Economic Sectors on Poverty. International Journal of Business, Economics, and Social Development, 2(1), 37-49.

Ramadhan, A., Sutandi, A., \& Pravitasari, A. E. (2020, August). Analysis of The Regional Development Level in Aceh Province. In IOP Conference Series: Earth and Environmental Science (Vol. 556, No. 1, p. 012008). IOP Publishing.

Sendouw, R. (2014). the economic growth and the regional characteristics: the case of indonesia. Buletin Ekonomi Moneter dan Perbankan, 16(1), 3-18.

Sukono, Saputra, J., Subartini, B., Purba, J. H. F., Supian, S., \& Hidayat, Y. (2019). An Application of Genetic Algorithm Approach and Cobb-Douglas Model for Predicting the Gross Regional Domestic Product by Expenditure-Based in Indonesia. Engineering Letters, 27(3), 411-420.

Suryahadi, A., Hadiwidjaja, G., \& Sumarto, S. (2012). Economic growth and poverty reduction in Indonesia before and after the Asian financial crisis. Bulletin of Indonesian Economic Studies, 48(2), 209-227.

Wintara, H., Masbar, R., \& Suriani, S. (2021). Determinants of Socio Economic and Demographic Characteristics of Poverty in Aceh Province. International Journal of Business, Economics, and Social Development, 2(2), 50-56.

Yang, F., Yang, M., Xue, B., \& Luo, Q. (2018). The effects of China's western development strategy implementation on local ecological economic performance. Journal of Cleaner Production, 202, 925-933.

Yudhistira, M. H., \& Sofiyandi, Y. (2018). Seaport status, port access, and regional economic development in Indonesia. Maritime Economics \& Logistics, 20(4), 549-568.

Yusri, N., Asmariati, R., \& Mardianto, R. G. (2018). Rencana Pengembangan Sentra Industri Kreatif Sebagai Tujuan Pariwisata (Studi Kasus: Kabupaten Pasaman). Jurnal Rekayasa, 8(2), 161-178. 